\title{
A review of ecological mechanisms for management practices of protective forests
}

\author{
Jiaojun Zhu ${ }^{1,2,3} \cdot$ Lining Song ${ }^{1,2,3}$
}

Received: 9 July 2020 / Accepted: 13 September 2020 / Published online: 27 October 2020

(C) The Author(s) 2020

\begin{abstract}
A protective forest, including shelterbelt, windbreak, and shelter forest as its synonyms, is characterized by the protective functions of various forest types distributed or planted on ecologically fragile areas or nearby the objects that need to be protected using the ecological effects of forests. Ecological mechanisms for management practices of protective forests is one of the disciplinary orientations in forest ecology and management. Most protective forest studies are dependent on forestry eco-engineering, such as the Great Plains Shelterbelt Project in the United States, the Great Plan for the Transformation of Nature in the Soviet Union, and the Three-North Afforestation Program in China. The development of sustainable management of protective forests has been given increasing attention by governments,
\end{abstract}

Project funding This work was supported by grants from the Key Research Program of Frontier Sciences, CAS (QYZDJSSW-DQC027), National Natural Science Foundation of China (31770757, 31770758), the Consultation Project supported by Divisions of the Chinese Academy of Sciences (2019-ZW09-A-032) and "Research on Development of Key Subjects in 2020-2021" from Ecological Society of China.

The online version is available at http://www.springerlink.com.

Corresponding editor: Yu Lei.

Jiaojun Zhu

jiaojunzhu@iae.ac.cn

1 CAS Key Laboratory of Forest Ecology and Management, Institute of Applied Ecology, Shenyang 110016, People's Republic of China

2 Qingyuan Forest CERN, Chinese Academy of Sciences, Shenyang 110016, People's Republic of China

3 Liaoning Key Laboratory for Management of Non-Commercial Forests, Shenyang 110016, People's Republic of China scientists, and media due to their impacts on environment conservation and global change. We introduce forestry ecoengineering and provide a review of their main ecological mechanisms for management practices of protective forests. Ecological mechanisms for management systems currently applied are emphasized, i.e., the theory of protection maturity and phase-directional management; the relationship between structure and protective functions and structural optimization measures; and, the decline mechanism and ecological restoration strategies. In addition, several unresolved problems in management practices of protective forests are discussed as well as the prospects for ecological mechanisms for management practices of protective forests in the future, which include: (1) theories and technologies for management practices of protective forests at the landscape or regional scale; (2) the decline mechanisms and corresponding ecological restoration approaches across multiple scales; and, (3) the comprehensive assessment of forestry eco-engineering at large-scales based on ecosystem principles.

Keywords Ecologically fragile areas $\cdot$ Ecological effects · Forestry eco-engineering · Management systems . Assessment of protective forests

\section{Introduction}

The protective function is a fundamental effect of forests, essential for human well-being (Motta and Haudemand 2000; Jiang et al. 2003). Generally, all forests have protective functions in various forms, e.g., contributing to water and soil conservation, preventing wind erosion, stabilizing mobile dunes, improving watershed management, and improving air quality (Franklin and Donato 2020). In other 
words, forests play an important role in protecting environments. However, forest resource decline is a severe problem worldwide, which results in increasing frequency and intensity of extreme events such as floods, droughts, high temperatures, sandstorms, and freezing damages (MoralesHidalgo et al. 2015). In addition, ecologically fragile areas also need to be protected by forests (Zhu 2013).

Protective forests are defined as specific forests that are planned (for natural forests) or planted on ecologically fragile areas and/or on other areas with natural hazards and or adverse climates. Based on the ecological effects of forests, they are planned or planted nearby populations or assets that need to be protected (Cao 1983; Motta and Haudemand 2000; Brang et al. 2006; Zhu 2008). Protective forests may be divided into shelterbelts (also known as windbreaks) and non-shelterbelt forests according to their shapes (Zhu 2013). Therefore, constructing protective forests (including planning and converting natural forests) has been adopted by many countries when confronted by natural disasters and ecological problems (Zagas et al. 2011). To date, there have been many large protective forest projects: the Great Plains Shelterbelt Project in the USA (Orth 2007), the Great Plan for the Transformation of Nature in the former Soviet Union (Brain 2010), and the Three-North Afforestation Program in China (Zhu and Zheng 2019). These forestry eco-engineering projects were initiated by the national authorities and set a precedent for establishing protective forests globally (Zhu 2013). Currently, the eco-engineering of protective forests has received increasing attention because of their protective benefits and environmental services, including sequestering $\mathrm{CO}_{2}$, considered to be a mitigation strategy for global climate change (Nair et al. 2010; Mayrinck et al. 2019; Amichev et al. 2020).

To promote healthy development of the eco-engineering objectives of protective forests, it is necessary to summarize the ecological mechanisms for management practices of protective forests (EMMPOPF). This review documents the state-of-knowledge of these management practices and identifies research gaps in EMMPOPF. Several key eco-engineering programs of protective forests are reviewed, with a particular focus on ecological mechanisms of management systems presently in use. Several unresolved problems encountered in management practices of protective forests are presented, as well the prospects for protective forests in the future. We expect our review to contribute to the development of a scientific framework and formulation of the best management practices of protective forests based on ecological mechanisms.

\section{Scope of EMMPOPF}

The ecological mechanisms for management practices of protective forests (EMMPOPF) is one of the disciplinary orientations in forest ecology and management. However, it is clearly different from conventional forest ecology and management for timber production because protective forests are focused on protective functions (i.e., ecological effects). The objective of EMMPOPF is to maintain the high efficiency, stability, and sustainability of protective functions based on ecological mechanisms (Jiang et al. 2003; Brang et al. 2006; Zhu 2013). EMMPOPF focuses on the theory of protection maturity and phase-directional management, the quantitative structure, the relationship between structure and protective functions and structural optimization measures, and the decline mechanism and ecological restoration strategies (Fig. 1).

Fig. 1 Frame of EMMPOPF

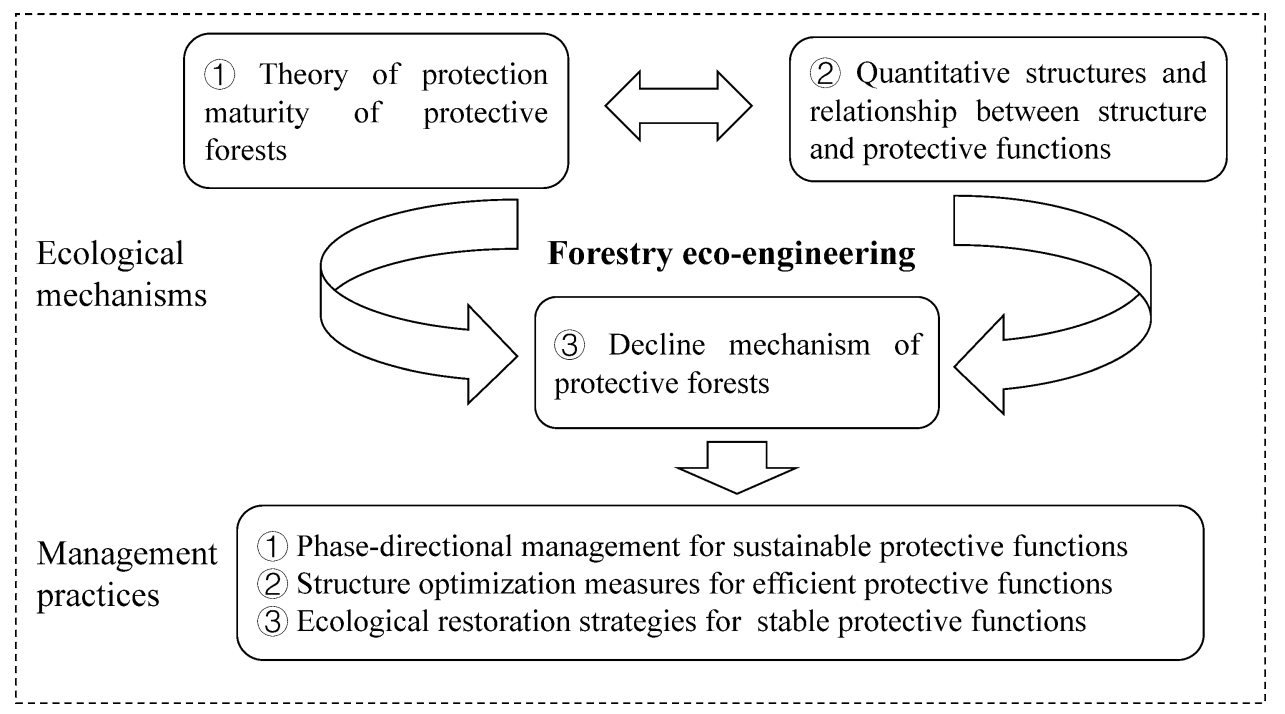




\section{Major eco-engineering of protective forests}

"Protective forest" is a general term for forests that has protective functions as the basic purpose or objective of management, including both plantation forests and natural forests (Zagas et al. 2011). Generally, protective forests can be classified by purpose or function such as farmland shelterbelts, animal husbandry windbreaks, sand fixation forests, water and soil conservation forests, and shelter forests for protecting roads, rail traffic, villages and buildings against avalanche, rockfalls, landslides, and floods (Brandle and Hintz 1988; Jiang et al. 2003). However, there are various definitions or classifications for protective forests worldwide, as they are specifically human-related. For example, protective forests in Italy and Switzerland are defined as forests that have primary functions for the protection of people or assets against the impacts of natural hazards (Brang et al. 2006). In Japan, the forests with management objectives for conserving water, preventing debris flow and soil erosion, and protecting the environment are classified as protective forests (Zhu 2013). In China, protective forests are divided into farmland shelterbelts, sand fixation forests, water and soil conservation forests, and coastal forests (Cao 1983). Most studies related to protective forests are dependent on forestry eco-engineering (Jiang et al. 2003; Gardner 2009; Zhu 2013) (Table 1 and Fig. 2).

\section{The Great plains shelterbelt project (Roosevelt engineering in the USA)}

In the United States, following severe and damaging dust storms of the 1930s, the newly elected president, Franklin D. Roosevelt, set about searching for solutions to the dust bowl on the Great Plains by initiating the Great Plains
Shelterbelt Project (GPSP, Roosevelt Engineering) in 1935 (Orth 2007). The GPSP's mandate was to plant shelterbelts during 1935-1942 across six Great Plains states, with $1,850 \mathrm{~km}$ long and $160 \mathrm{~km}$ wide covering 30 thousand farms to protect crops and wildlife from desiccating winds, to intercept blowing snow and sand, and to provide wood products (Fig. 2). By 1942, 30,233 shelterbelts had been planted, stretching $29,927 \mathrm{~km}$ from North Dakota to Texas, protecting 30,200 farms of 1.62 million ha (Gardner 2009). A survey of shelterbelts in 1944 declared that the GPSP was successful, with approximately $80 \%$ of the shelterbelts rated as good or better (Gardner 2009). However, by 1954, only $42 \%$ were in good condition. Some were removed in the 1970 s as a result of the introduction of irrigation systems (Ghimire et al. 2014). Other shelterbelts had died because of drought, pests, and grazing (Orth 2007). Despite an educational campaign and the conservation efforts by the government agencies, the number of shelterbelts on the Great Plains has decreased, and the conditions of the remaining are deteriorating (Ghimire et al. 2014). Most of the shelterbelts in the Great Plains have declined or died due to less management and to frequent human and natural disturbances.

\section{The Great plan for the transformation of nature (Stalin's plan in the Soviet Union)}

To combat drought, increase soil fertility, curtail soil erosion by wind and water, and facilitate the rational use of land, the Great Plan for the Transformation of Nature (GPTN), also known as Stalin's plan for the transformation of nature, was implemented by the government of the Soviet Union in 1948 (Brain 2010; Shaw 2015). The GPTN's goal was to establish 5.7 million ha of forests in southern Russia (Fig. 2), in which their centerpiece was to be eight enormous shelterbelts

Table 1 Overview of major forestry eco-engineering programs world-wide

\begin{tabular}{|c|c|c|c|}
\hline Programs & Countries & Duration & Scope $\left(\times 10^{4} \mathrm{~km}^{2}\right)$ \\
\hline The Great Plains Shelterbelt Project & USA & $1935-1942$ & 18.5 \\
\hline The Great Plan for the Transformation of Nature & Russia & $1949-1965$ & 560 \\
\hline The Forestry and Water Conservation Projects & Japan & $1954-1983$ & 38 \\
\hline The Green Dam Project in Five Countries in North Africa & $\begin{array}{l}\text { Algeria, Egypt, Libya, } \\
\text { Morocco, and Tunisia }\end{array}$ & $1970-1986$ & 2.25 \\
\hline The Green Plan & Canada & $1970-2000$ & 49 \\
\hline The Social Forestry Program & India & $1973-2012$ & 56 \\
\hline The Three-North Afforestation Program & China & $1978-2050$ & 406.9 \\
\hline The National Forestation Program & Philippine & $1986-2015$ & \\
\hline $\begin{array}{l}\text { Shelterbelt Systems in the Middle and Upper Reaches of the Yang- } \\
\text { tze River Basin }\end{array}$ & China & 1989-2029 & 220.61 \\
\hline The Natural Forest Conservation Program & China & $1998-2050$ & 41.33 \\
\hline The Project Returning Farmland to Forestry & China & $1999-2050$ & 7.13 \\
\hline The Beijing-Tianjin Sandstorm Control Program & China & $2001-2012$ & 45.8 \\
\hline
\end{tabular}




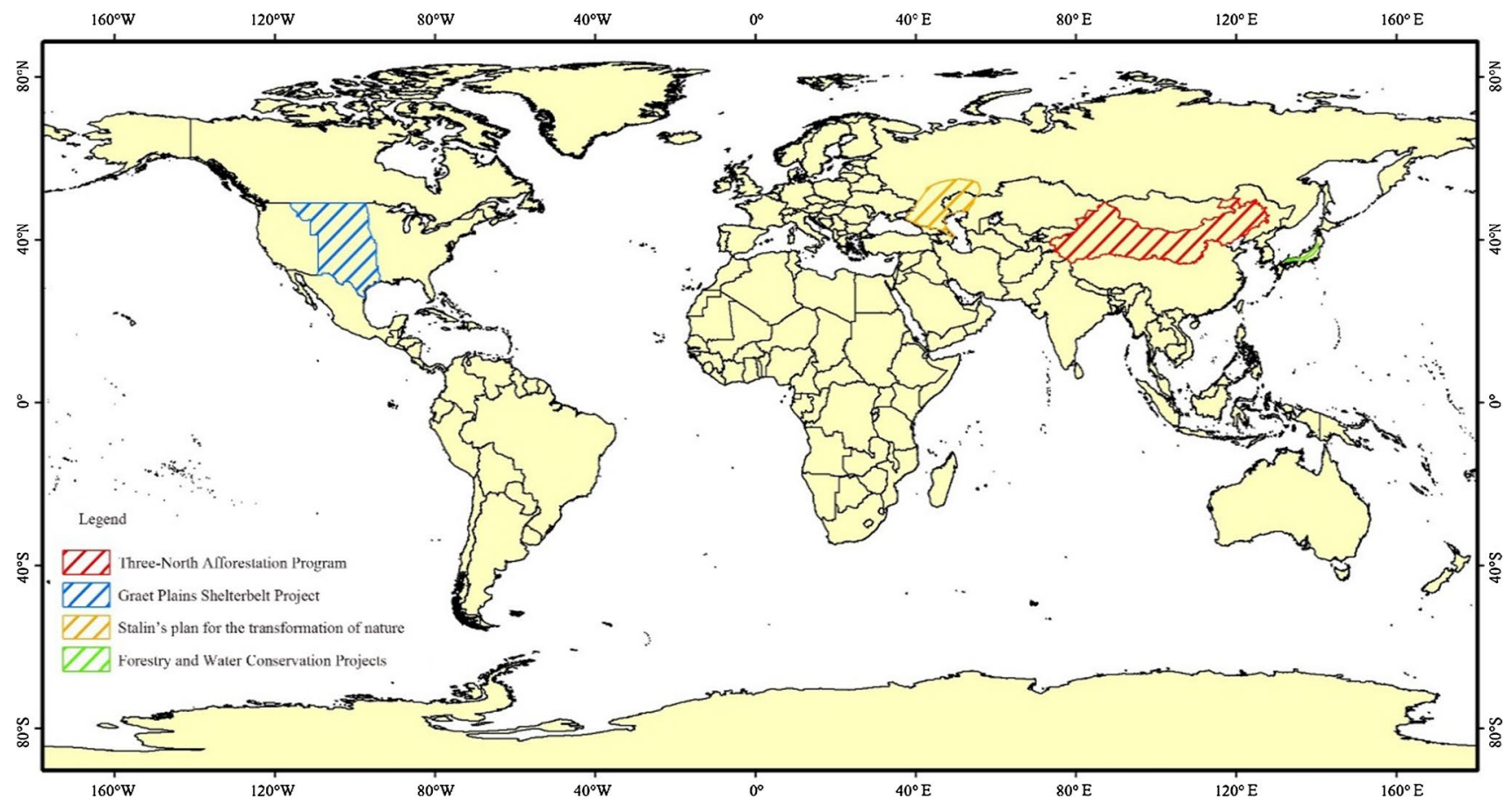

Fig. 2 Distribution of well-known forestry eco-engineering

totaling $5320 \mathrm{~km}$ in length and covering 118,000 ha; it is also called the state-centered farmland shelterbelt program (Brain 2010). The GPTN intended to plant forests across 16 provinces and 204 districts, over an area equal to that of Britain, France, Italy, Belgium, and the Netherlands combined, and was scheduled to be completed by 1965 . More than 2.87 million ha of shelterbelts had been planted by 1953, and the number increased to 5.0 million ha in 1987 , which protected one million ha of pasture and 40 million ha of farmland. Annual grain production was improved by 40-45 million tons with the protection of these shelterbelts (Josephson 2019). However, most of the shelterbelts have now died due to the lack of management and the change of the former Soviet Union (Shaw 2015).

\section{The Forestry and Water Conservation Projects in Japan}

Water and soil losses, debris flows, landslides, and other natural hazards occur frequently in Japan, especially following the Second World War, aggravated due to extensively destroyed forests. The Forestry and Water Conservation Projects (FWCP) were initiated in 1954 and lasted until 1983 (Fig. 2). During 1954 and 1963, most of the protective forests had been planted or classified from natural forests for controlling soil losses; the water conservation forests had been established during 1964 and 1973. With rapid urbanization from 1974-1983, the healthy urban and water conservation forests had been established. From 1984-1991, concrete dams had been constructed in mountainous areas prone to natural hazards for preventing erosion and stopping unstable sediments. By 2008, the area of the protective forests accounted for $31.4 \%$ of the total area of Japan, with various protective forest networks. Water and/or soil conservation forests are the primary protective forests, accounting for $90 \%$ of the total area of protective forests. More than $70 \%$ of the protective forests are state-owned, but a lack of management results in lower protective functions (Iwasaki et al. 2019).

\section{The Three-North Afforestation Program and other forestry eco-engineering programs in China}

Protective forests have been planted for more than 100 years because of ecological stresses in the country (Cao 1983). Large-scale protective forest programs were started from the founding of the People's Republic of China (Song et al. 2020). For protection against severe natural hazards and solving ecological problems such as desertification, sand/ dust storms, and water and soil losses in the Northeast, North, and Northwest (Three-North), the world's largest protective forest project, the Three-North Afforestation Program (TNAP) was initiated in 1978, and is ongoing to 2050 (Zhu and Zheng 2019). The TNAP was initially planned to be implemented across 551 counties of 13 provinces in the Three-North region, with an east-west length of $4480 \mathrm{~km}$ 
and a south-north width of 560-1460 km (a total area of 4.07 million $\mathrm{km}^{2}$, covering $42.4 \%$ of China's entire territory) and covering more than $95 \%$ of wind-blown sandy areas and $40 \%$ of water and soil loss areas (Fig. 2). The afforested area of TNAP is expected to be 37.3 million ha. After 40 years (1978-2017) of implementation of TNAP, the area of sand fixation forests increased by $154 \%$, and water and soil conservation forests by approximately $69 \%$ (Zhu and Zheng 2019). After TNAP, a series of forestry eco-engineering projects such as Shelterbelt Systems in the Middle and Upper Reaches of Yangtze River Basin (SSY), the Natural Forest Conservation Program (NFCP), the Project of Returning Farmland to Forestry (PRFF), and the Beijing-Tianjin Sandstorm Control Program (BTSCP) have been initiated and carried out.

In addition to the protective forest projects or forestry eco-engineering programs mentioned above, other protective forest projects have been implemented such as the Green Dam Project of the Five Countries in Northern Africa (Algeria, Egypt, Libya, Morocco, and Tunisia) (1970-1986), the Social Forestry Program in India (1973-2012), the National Forestation Program in the Philippines (1986-2015), and the Green Plan in Canada (1970-2000) (Table 1). These eco-engineering programs of protective forests have significantly increased forest resources and played key roles in protecting populations from natural hazards, increasing crop yields, and improving ecological environments (Orth 2007; Brain 2010; Zhu and Zheng 2019). However, there are numerous issues of low afforestation rates, severe dieback or decline, and low quality which negatively affect the protective functions (Burke et al. 2019; Zhu and Zheng 2019). The absence of management based on ecological mechanisms and both human and natural disturbances aggravate these problems. To exert protective functions efficiently and continuously, it is urgent to manage protective forests based on theories and technologies of ecological mechanisms for management of protective forests.

\section{Ecological Mechanisms for Management Practices of Protective Forests (EMMPOPF)}

The major goal of protective forest management is to ensure efficient and effective protective functions over as long a period as possible (Brang et al. 2006; Zhu 2008). Therefore, management practices are to maintain forest stability in providing reliable, continuous protective functions in keeping the optimum structure and vitality in the face of internal and external influences based on ecological mechanisms (Motta and Haudemand 2000). Since the late 1970s, with the development of reform and opening up, China has established the largest area of protective forests worldwide, which promotes the rapid development of EMMPOPF study. Particularly, in the past four decades, the theory and technology of protective forest management based on ecological mechanisms have been substantially developed (Jiang et al. 2003; Zhu and Zheng 2019).

\section{Theory of protection maturity of protective forests and phase-directional management}

\section{Theory of protection maturity of protective forests}

Forest maturity, including technical, quantitative, economic and regeneration maturity, are core objectives of timber forest management. Likewise, protection maturity is the principal aim of protective forest management (Jiang et al. 2003; Zhu 2013). Several studies suggest that the protection maturity of protective forests was quantitative maturity (Chavasse 1982). Other studies defined protection maturity as the state where the protective function is at its peak (Bayoumi 1977). For instance, Stange (1996) considered the protective function maximized its value as protection maturity. Obviously, the quantitative maturity or maximum protective function is appropriate for timber forest management but is not fully suitable for the management of protective forests. Therefore, Jiang et al. (2003) proposed that the protection maturity of protective forests should be defined as "a state of protective forests which achieve effective and complete protection for the objects needed to be protected during their development of growth". The duration of protection maturity is determined by the starting and ending points, defined as the initial protection maturity age (IPMA) and terminal protection maturity age (TPMA), respectively. The goal of management practices is to maintain the duration of protection maturity as long as possible (Fig. 3).

\section{Phase-directional management}

Determination of the phases of growth and development (PGD) of forests is an important basis for management and has a direct influence on management practices (Jiang et al. 2003). Likewise, the division of PGD of protective forests is vital for management practices. Some studies reported that the PGD of protective forests could be divided into juvenile, middle age, near-mature, mature and over-mature phases based on variations in the relationships between trees and environment (Pisarenko et al. 2001). However, other studies have divided the PGD into different phases (management) according to protective functions (Wang et al. 2000; Mize et al. 2008), e.g., the formation of stands, initial protection, protection maturity, and decline of protection phases. To meet the special demands for achieving the state of protection maturity as soon as possible and as long as possible (Fig. 3), protective forest management practices can be divided into three phases by IPMA and TPMA during a 


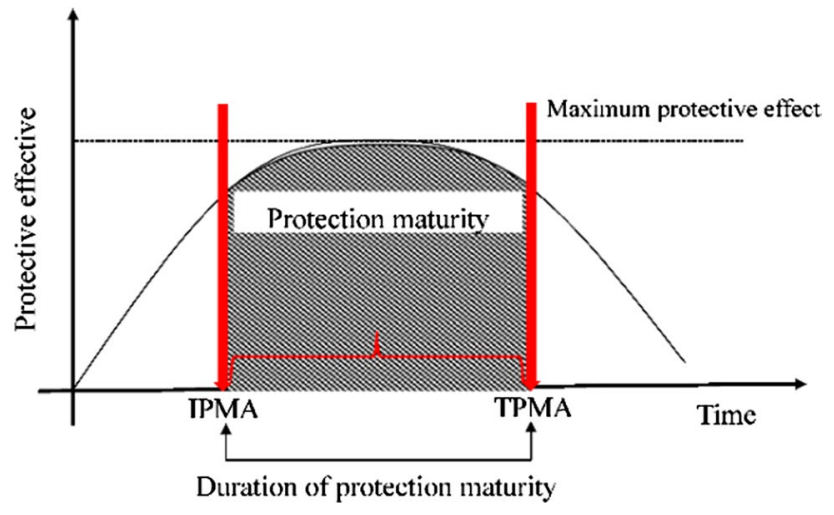

Fig. 3 Schematic diagram of the protection maturity of protective forests. IPMA: initial protection maturity age; TPMA: terminal protection maturity age ( modified from Jiang et al. 2003)

rotation: the pre-maturity period, maturity period (duration of protection maturity), and regeneration period (Jiang et al. 2003). The pre-maturity period is determined from reforestation, afforestation or planning of protective forests up to the IPMA phase. The aim during this period is to achieve protection maturity or reach IPMA as soon as possible. Tending techniques, e.g., weed clearing, soil cultivation, irrigation, fertilization, intercropping, and branch pruning, should be undertaken to accelerate the development of protective forests. In the maturity period or the duration of protection maturity (during IPMA and TPMA), tending techniques, e.g., thinning and pruning, should be carried out to maintain a reasonable structure for providing optimum protection. The final regeneration period is determined according to regeneration patterns and protection aims, perhaps from the TMPA phase to the natural maturity of protective forests, in which the objective of management is to accelerate regeneration and recover the protection maturity. Thus, selective cutting, shelterwood cutting, and natural regeneration with artificial promotion of regeneration should be operated timely (Zhu 2013) (Fig. 3). Overall, the management practices of protective forests are directional-toward accelerating or retaining the protection maturity through the three phases. The theory and technical measures mentioned above are mainly applicable to protective forest plantings, but the principles for the management of natural protective forests are similar to those applied to planted protective forests (Zhu 2013).

\section{Quantitative structures and their relationships to protective functions and structural optimization measures}

As with other ecosystems, the structure of protective forests determines the protective functions. Structure is considered as the distribution patterns of stems, branches, and leaves in a protective forest stand or a shelterbelt, which is determined by species, composition (tree, shrub, and grass), tree arrangement patterns, and parameters such as diameter at breast height, height, age, and stem densities (Zhu 2013; Thuyet et al. 2014). How to define the structure parameters of protective forests and how to use them in management practices to meet various objectives are key research components in EMMPOPF.

\section{Quantitative structures of shelterbelts and their relationships between protective functions}

The most commonly applied descriptor of the shelterbelt structure is porosity (Kenney 1987; Loeffler et al. 1992; Zhou et al. 2002), defined as the ratio or percentage of pore space to the space occupied by tree elements. It reflects a three-dimensional aerodynamic structure of a shelterbelt (Cao 1983; Zhou et al. 2005) that affects the turbulence levels in and around the shelterbelt. Because it was nearly impossible to measure the aerodynamic porosity of a shelterbelt physically, much effort has been directed toward finding an alternative measurement of porosity, i.e., optical porosity, a two-dimensional measure of porosity. The optical porosity, defined as a simple ratio of perforated area to total area on the vertical section of a shelterbelt, has been adopted as a descriptor of shelterbelt structures (Kenney 1987; Loeffler et al. 1992; Jiang et al. 2003; Wu et al. 2018). Optical porosity is a particularly promising alternative to the aerodynamic porosity of narrow shelterbelts, as the optical porosity of narrow shelterbelts is much closer to aerodynamic porosity. Besides optical porosity, shelterbelt height, orientation, length, width, cross-sectional shape (for multi-row shelterbelts), and continuity and uniformity are the parameters related to shelterbelt structures (Zhu 2008). These parameters play different roles in controlling shelterbelt structures. For example, height is the most important factor determining the extent of the protected zone (Zhu 2008); the effectiveness of a shelterbelt is reduced when orientation is not perpendicular to the problem winds; the continuity and uniformity influence the shelter efficiency (any gap or separation in a shelterbelt will concentrate wind flow) (Zhou and Sun 1994; Zheng et al. 2016).

Shelterbelts on farmlands provide favorable microclimate conditions for crops (Cao 1983). Most studies show that shelterbelts could reduce wind speeds on the leeward side, and the reduction depended on the optical porosity, height, shape, and width of the shelterbelts (Cao 1983; Brandle et al. 2004). For example, maximum wind reductions are closely related to porosity, with low porosity producing high maximum reductions (Heisler and Dewalle 1988). Because of the favorable microclimate conditions provided by shelterbelts, crop yields can increase 10-30\% (Cao 1983; Brandle et al. 2004; Iwasaki et al. 2019). Although a few studies on the effects of shelterbelts on microclimates and crop yields at 
landscape levels have been conducted (Deng et al. 2011; Osorio et al. 2019), by Zheng et al. (2016), the influence of the protection levels on crop yields in different climatic productivity zones at a landscape scale had been quantified. They reported that maize yields increased steadily as levels of protection increased up to $80 \%$, and decreased thereafter in zones with high and middle climatic potential productivity. However, in the zone with a low climatic potential productivity, maize yields increased gradually as the level of protection increased up until 50\%, remained relatively constant between protection levels of $50-80 \%$, and decreased thereafter.

\section{Quantitative structures of non-shelterbelt forests and relationships between protective functions}

Stratification is a useful tool for defining vertical structures of non-shelterbelt forests (Thuyet et al. 2014). Similarly, stratification porosity defines the distribution of pores calculated vertically, i.e., cutting a non-shelterbelt forest into many slices (similar to computed tomography images) in the vertical direction and computing the porosity (Zhu et al. 2003). Stratification porosity has a similar definition to that of shelterbelt porosity (the ratio of the perforated space to the space occupied by tree stems, branches, twigs, and leaves, from the top of a non-shelterbelt forest to a horizontal plane above a given height). Optical stratification porosity (OSP), a two-dimensional metric determined from non-shelterbelt forest silhouettes in a vertical section, is the alternative to the stratification porosity (Zhu et al. 2003). The OSP represents the proportion of the sky hemisphere not obscured by tree elements downward to a horizontal plane at a given height inside a non-shelterbelt stand. An individual OSP is determined as the ratio of the pore area to the total area using non-shelterbelt forest silhouettes in a vertical direction on a horizontal plane at a given height. As a descriptor of vertical forest structure, the OSP has the potential to describe the distribution of light, airflow, and rainfall inside the non-shelterbelt stand. These factors, in combination, determine temperature, humidity, and even soil moisture conditions within the non-shelterbelt forests (Zhu et al. 2003). Similar to the OSP, canopy cover, closure, and gap are frequently used by ecologists and foresters to indicate the vertical projection of canopy (Vales and Bunnell 1988), which can be derived from the OSP measurement.

Non-shelterbelt forests (e.g., water and soil conservation forests and sand stabilization forests) play an important role in preventing water and soil erosion by intercepting rainfall by the canopy, reducing splash by litter and the understory, and limiting soil particle movement by the root systems (Zhao et al. 2015) and controlling desertification by reducing wind erosion (Wang 2004; Vacek et al. 2018). Most studies show that the canopy could intercept $10-40 \%$ of gross rainfall (Miralles et al. 2010; Li et al. 2017), which is influenced not only by rainfall events but also by the OSP, vegetation types, stand composition, and stand age. For example, canopy interception loss of water and soil conservation forests decreased with increasing the OSP (Limousin et al. 2008; Park and Cameron 2008), and natural vegetation has a gradually increased effect on water and soil conservation from natural grasslands to shrubs and trees (Zhao et al. 2015). In addition, wind erosion control by sand stabilization forests was influenced by vegetation coverage, structure, and distribution pattern (Vacek et al. 2018). Several studies showed that vegetation coverage above a certain threshold could protect surface soil, reduce wind speeds, and thus prevent dust entrainment and transport in the process of wind erosion (Huang et al. 2001; Amichev et al. 2015). Moreover, given the similar vegetation coverage, an evenly scattered pattern provides more effective protection from wind erosion than a clustered pattern (Dong et al. 1996).

\section{Structural optimization measures based on relationships between structures and protective functions}

The appropriate spatial arrangement, adequate biodiversity, and ecosystem stability of protective forests can maximize protective functions (Zhu 2008; Jose 2012). Structure optimization for protective forests is the process whereby optimum structures are selected and maintained (Cao 1983; Thuyet et al. 2014; Wu et al. 2018).

Structural optimization measures for shelterbelts When considering shelterbelts, the estimation of optical porosity is generally determined by the digital image method (Kenney 1987; Jiang et al. 2003). Optical porosity can change the behavior of wind passing through a shelterbelt and further influence the protection distance (Brandle and Hintz 1988; Zhu 2008). Therefore, the optimum optical porosity can be determined by establishing relationships between optical porosity and wind speed reduction (Jiang et al. 2003; Wu et al. 2018). There is considerable variation in optimum optical porosity which might be caused by differences in shelterbelt composition, the effects of thermal instability in the field, and the types of instruments used (Cao 1983). Most studies have demonstrated that optimum optical porosity ranged from $0.20-0.40$ (Wu et al. 2018), e.g., 0.25 for poplar shelterbelts in Northeast China (Jiang et al. 2003), 0.19 for coniferous shelterbelts (Grant and Nickling 1998), and 0.20-0.35 for forest models in wind tunnel experiments (Cornelis and Gabriels 2005). However, few studies focus on the relationship between shelterbelt porosity and wind reduction at the landscape or regional levels (Zheng et al. 2016). Optical porosity is mainly determined by the characteristics of foliage and branches of individual trees or shrubs. Therefore, the way to obtain the optimum 
optical porosity is to modify the tree species or the spacing within and between tree rows, or by using other measures such as thinning, pruning, and adding shrub borders (Jiang et al. 2003). For example, Ge and Bi (2018) investigated the optical porosity of poplar shelterbelts in the plain regions of Heilongjiang Province, China. They found that more than half of the shelterbelts deviated from the optimum optical porosity; modifying the species and increasing the proportion of mixed forests were proposed to achieve the optimum optical porosity.

Structural optimization measures for non-shelterbelt forests Similar to the optimum optical porosity of shelterbelts, the optimum OSP (optimum stratification porosity) of a non-shelterbelt forest can be determined by establishing relationships between OSP and ecological factors influencing the protective functions (Zhu et al. 2003). According to the definition of OSP, it increases with incremental changes of height and attains a maximum value of 1.0 (pore proportion of $100 \%$ ) when it reaches or surpasses the canopy top.

The distribution of OSP in a vertical direction is based on Lambert's law (Zhu et al. 2003):

$\mathrm{OSP}=\mathrm{OSP}_{0} \exp \left[-v\left(1-\frac{z}{H}\right)\right]$

where, $\mathrm{OSP}_{0}$ is 1.0 as the measurement starts from the canopy top, $\nu$ is the extinction coefficient in Lambert's law, $z$ is height within the stand, $H$ is the height of canopy) (Zhu et al. 2003).

OSP is related to species composition, the competitive relationship, environmental constraints, and disturbances. Therefore, the vertical strata of a non-shelterbelt stand can be identified using the extinction coefficients obtained from OSP measurements. The optimum OSP, defined as vertical stratification that could maintain the maximum protective effect, varies greatly among various categories of protective forests (Zhu et al. 2003), but it can be obtained by thinning, pruning, and replanting (Zheng et al. 2012; Yang et al. 2017; Song et al. 2020).

\section{Decline mechanism of protective forests and ecological restoration strategies}

The health and stability of protective forests are the prerequisites for carrying out protective functions efficiently (Zhu 2013). However, protective forests have declined during their growth and development due to various reasons. The decline phenomena include dieback, low growth rates, mortality, and scarce regeneration (Zhu et al. 2008). Therefore, mechanism studies corresponding to their decline have been conducted (Sun et al. 2018; Masaka et al. 2020; Song et al. 2020), most focused on planted protective forests, e.g., Pinus sylvestris var. mongolica Litv. sand stabilization forests (Song et al. 2009), Populus spp. protective forests (Arundell and Straw 2001; Ji et al. 2020), and Betula platyphylla Suk. shelterbelts (Masaka et al. 2020).

\section{Decline mechanisms of protective forests}

Species incompatible with site conditions Matching tree species to site conditions is essential for effective management practices of protective forests (Cao 1983; Mize et al. 2008). When the species are unsuitable to the site, poor growth, dieback, and ultimately mortality occur. For example, decline of some protective forests in the Three-North Afforestation Program was the result of mismatching species with site conditions (Zhu and Zheng 2019). In addition, native species and the zonal climax vegetation types were not considered in the selection of species, which also led to protective forest decline (Song et al. 2009). For example, large-scale afforestation with $P$. sylvestris var. mongolica on arid and semi-arid sandy lands was in contrast with the regional succession climax, sparse wooded grasslands; consequentially, dieback and mortality occurred due to serious water stresses (Song et al. 2020).

Lack of effective management Effective management of protective forests contributes to their stability for providing protective functions reliably and continuously (Song et al. 2009). However, many protective forests are improperly managed due to a lack of management procedures or of understanding the management phase. In the pre-maturity period, weeding, pruning, and thinning can accelerate the development of protective forests and achieve protection maturity earlier. However, no silvicultural steps are implemented after afforestation for some protective forests, leading to weeds competing for water and nutrition with seedlings or saplings (Jiao 2001) and insufficient light conditions. Consequently, the growth of seedlings and saplings is limited, even resulting in mortality (Jiang et al. 2003; Song et al. 2009). In addition, reduction of stem density should be applied to improve the ecological health of protective forests when they are obviously differentiated in diameter at breast height; otherwise, poor growth or decline occurs (Jiang et al. 2003; Song et al. 2009). In the maturity period, major silvicultural thinning and pruning are needed to maintain a reasonable structure for optimum protection. Untimely thinning or pruning will result in an unreasonable shelterbelt structure and reduce optimum protection. For example, for higher initial planting density of $P$. sylvestris var. mongolica protective forests in semi-arid sandy lands, thinning is not carried out within the maturity period; soil 
water was excessively consumed and thus the water levels became imbalanced and caused dieback and mortality (Zhu et al. 2008; Song et al. 2020). In the regeneration period, if the protective forests are clear-cut, there are no protective functions. Therefore, selective and shelterwood cutting and natural or artificial regeneration may be expected (Jiang et al. 2003).

Natural disturbances Natural events such as drought, extreme temperatures, pests, and disease play key roles in forest ecosystem dynamics (Thom and Seidl 2016). Similar to other forest ecosystems, natural disturbances affecting protective forests induce dieback and mortality. One of the most critical natural disturbances may be drought induced by climate change. The increased frequency and intensity of drought and heatwaves at regional or global scales negatively influence the stability and health of protective forests located in arid and semi-arid areas (Song et al. 2020). Drought results in water stress and damage to physiological processes (e.g., hydraulic failure and carbon starvation) (Jiao 2001; Sun et al. 2018; Song et al. 2020). Numerous studies have linked widespread dieback and mortality of protective forests to drought-induced water stress and extreme changes in temperature and rainfall (Sun et al. 2018). Additionally, extremely high temperatures results in the failure of natural regeneration in some sand stabilization forests, e.g., $P$. sylvestris var. mongolica; this ectomycorrhizal fungusdependent species failed to naturally regenerate because of high temperatures causing fungus death within $5 \mathrm{~cm}$ of the soil surface (Zhu et al. 2008). Extreme drought and temperatures, and elevated $\mathrm{CO}_{2}$ concentrations are expected to magnify pests and disease pressures on protective forests (Morales-Hidalgo et al. 2015). Extended warmth during drought periods can drive increased population abundance of these biotic agents, allowing them to overwhelm already stressed tree hosts (Masaka et al. 2020). Current studies suggest that dieback and mortality of protective forests commonly involve multiple and interacting factors, ranging from drought to insect pests and diseases (Song et al. 2009). In the European Alps, Picea abies (L.) H. Karst-dominated mountain forests are particularly vulnerable to dieback and mortality under climate change due to the increased risk of bark beetle outbreaks and drought (Brang et al. 2006; Lexer and Bugmann 2017).

Human disturbances With increasing in populations, anthropogenic disturbances such as deforestation, overgrazing, and firewood collection have become important factors affecting the stability of protective forests (Song et al. 2009). Deforestation is a major threat as it results in soil erosion and loss of nutrients, and biodiversity (Zhu and Zheng 2019). In addition, grazing and surface trampling reduce the infiltration of water, increase runoff and erosion (Zhu and Zheng 2019), and affect regeneration by damaging seedlings (Fischer et al. 2009). Furthermore, firewood collection also induces the decline of protective forests (Song et al. 2009) because it not only removes nutrients but also increases soil evaporation and reduces soil water availability.

Land-use change Land-use changes, one of the major drivers of environmental change (Schößer et al. 2010), have profound effects on seedling recruitment, tree growth, water balances, and long-term stability of protective forests at a landscape scale, further leading to their decline. Research on the effects of land-use changes on the decline of $P$. sylvestris var. mongolica (MP) sand stabilization forests has been carried out in southern Horqin Sandy Land, Northeast China (Zheng et al. 2012). These forests, introduced to control erosion in the 1950s, showed dieback and decline at the beginning of the 1990s. At the same time, a linear decrease in the groundwater table was found during 1954-2009 (Fig. 4a). Most studies suggest that water stress induced the dieback and decline because these forests consumed considerable water resources (Jiao 2001). However, the dynamics of land-use changes made the decline process clear, i.e., before 1953, the land surrounding the sand stabilization forests consisted primarily of degraded grasslands and bare sandy land with the groundwater at $0.7 \mathrm{~m}$ (Figs. $4 \mathrm{a}$ and 5a); following the establishment of the protective forest, the surrounding environment improved but accompanied by expanding agricultural dry fields through 1979 (Fig. 5b). The area of broadleaved protective forests then increased due to the manifestation of sand stabilizing forests, and the area of agricultural dry fields further expanded (Fig. 5b). As vegetation cover increased in the MP (sand stabilizing) forest area, water consumption increased and groundwater declined to $4.0 \mathrm{~m}$ in 1988 (Figs. 4a and 5c). However, water consumption by the MP (coniferous) forest was only $12.5 \%$ of the resource over the past five decades (Fig. 4b). The roots of $P$. sylvestris var. mongolica are distributed primarily within the upper $100 \mathrm{~cm}$ soil layer (95\% roots); therefore, MP forests mainly use the available water at depths $<100 \mathrm{~cm}$. However, when soil moisture does not meet the water requirements of the species, they have to absorb groundwater directly or indirectly through the capillary rise of groundwater. After 1988, the reclaimed paddy fields and the rapid increase of poplar forests further accelerated the lowering of water table. Consequently, MP forests experience difficulty taking up underground water. When precipitation was extremely low, MP forests were particularly subject to dieback (Figs. 5d and 5e), i.e., the land-use changes caused groundwater levels to decrease and aggravated soil drying, which led to the decline of MP forests (Zheng et al. 2012). 


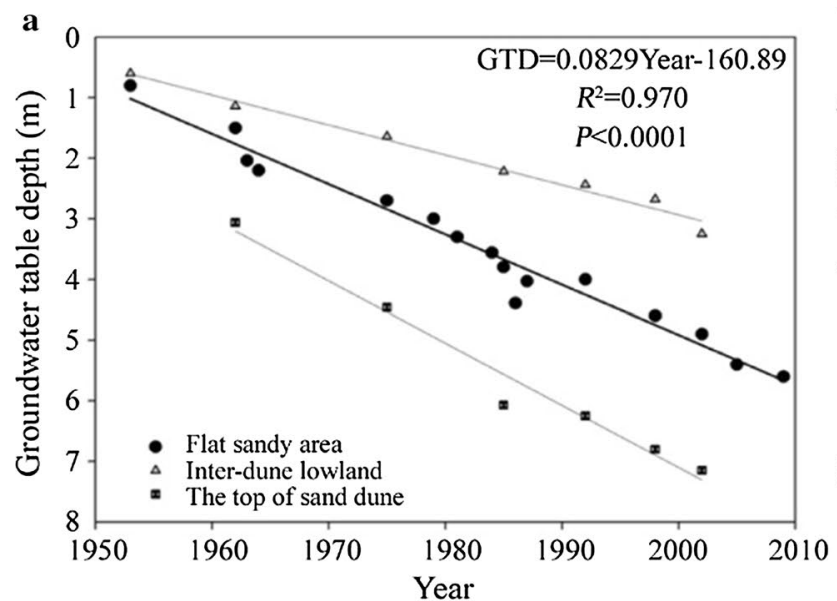

Fig. 4 Variations in groundwater table during 1953-2009 in Horqin Sandy Land (a) and water consumption of land use types, including by households, bare sandy land, grassland, shrubland, conifer-

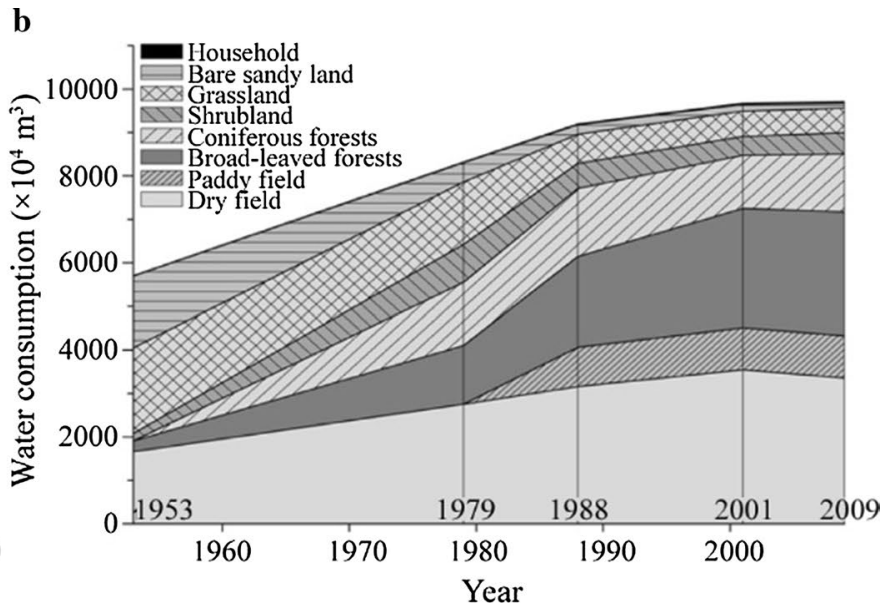

ous (MP) forests, broad-leaved (poplar) forests, paddy fields and dry fields during 1953-2009 (b) (reprinted from Zheng et al. 2012, with permission from Elsevier) $\mathbf{a}$

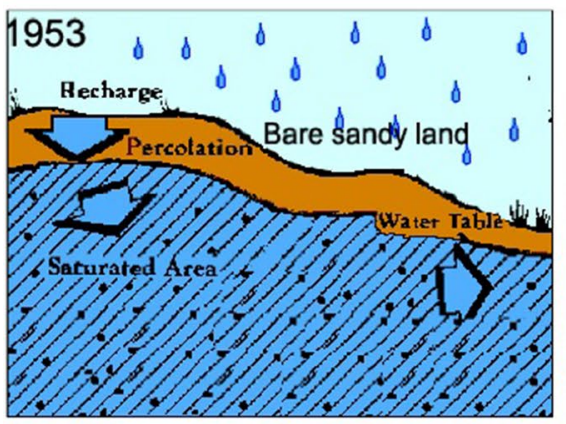

d

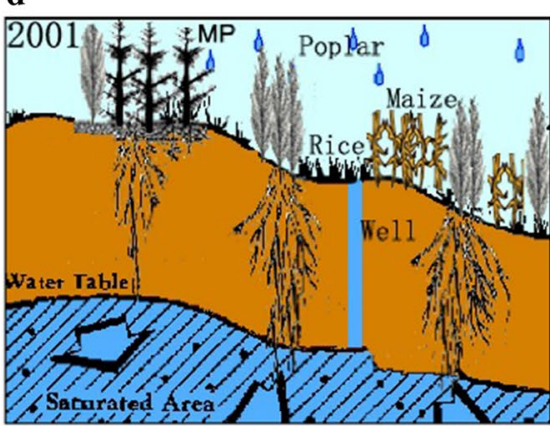

b

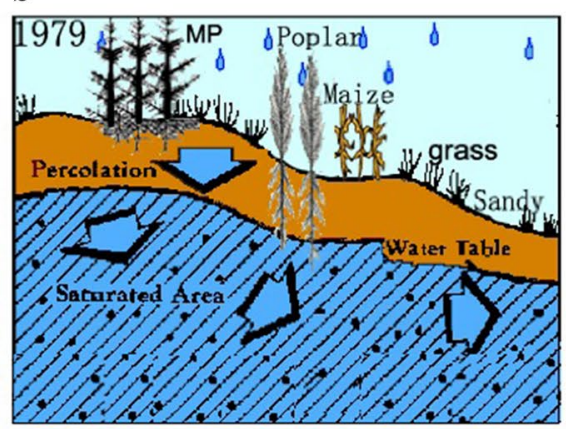

e
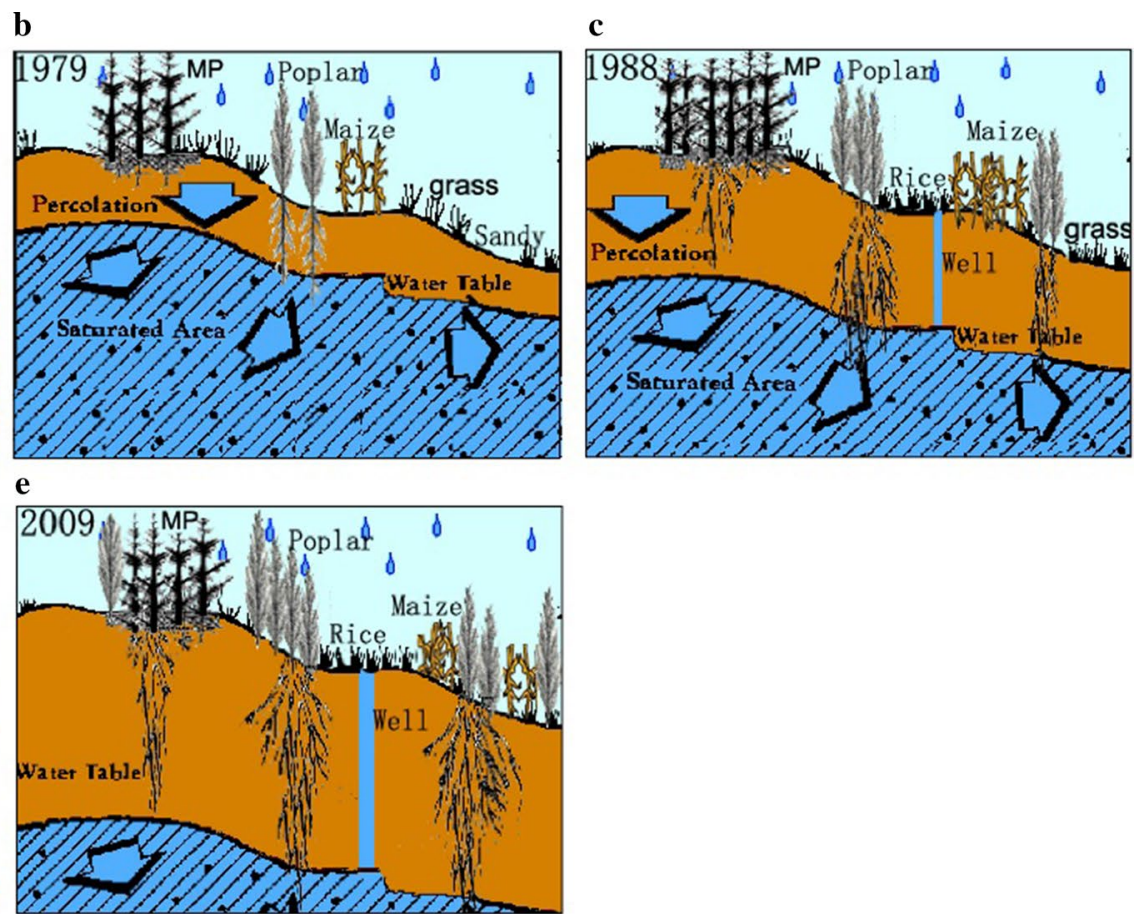

Fig. 5 Processes of land-use changes and the decline of P. sylvestris var. mongolica sand fixation forests during 1953-2009 (reprinted from Zheng et al. 2012, with permission from Elsevier)

\section{Ecological restoration strategies}

Some measures have been put forwarded to prevent or to control protective forest decline according to decline causes (Jiang et al. 2003; Zhu and Zheng 2019). Early diagnosis is one important measure to prevent protective forest decline, which allows for early control (Du et al. 2002; Song et al. 2009). Several studies have proposed that re-planning the construction of the protective forests, afforestation with species referenced to the zonal vegetation and close to natural 
forests based on water resource carrying capacity are important strategies (Song et al. 2009; Ren et al. 2018). For example, Zhu and Zheng (2019) reported that re-planning the construction regions of the Three-North Afforestation Program was an important measure to avoid the decline of protective forests due to not matching the tree species with site conditions. In addition, enhancing management procedures based on the theories and technologies for the management of protective forests are also major strategies to address the absence of sound management, e.g., adjustment of protective forest structure and enrichment planting (Mize et al. 2008; Zhu and Zheng 2019). Furthermore, fencing is an important measure to reduce human disturbances of protective forests (Contreras-Hermosilla 2000; Jiang et al. 2003). Regeneration and transformation are also principal measures based on ecological restoration to address protective forest decline induced by land-use changes (Zhu 2013; Mayrinck et al. 2019).

\section{Future Research}

This review has created a summary to help understand the role of protective forests in improving ecological environments. However, ecological mechanisms for management of protective forests are subject to the levels of social and economic development of each country, to the distribution of ecologically vulnerable areas or climates, and to both national and international policies on environmental conservation (Nerlich et al. 2013). Thus, each research program on ecological mechanisms for management of protective forests may be unique but there are common principles.

\section{Theories and technologies for the management of protective forests at a landscape or regional scale}

The current theories and technologies for the management of protective forests were established at the stand/windbreak levels and are unsuitable at landscape or regional scales. Therefore, new methodologies should be established on principles of ecosystem management (Zhu and Zheng 2019). The structural optimization of protective forests should be upgraded to landscape or regional scales. In addition, the relationships between structure and protective functions of protective forests at these higher should be investigated to meet the demands of establishing and managing protective forest ecosystems. In addition, research on the structural optimization of protective forests in different climates and site conditions across multiple scales is necessary, as protective forests are widely distributed in a range of ecologically fragile areas globally.

\section{Decline mechanisms and corresponding ecological restoration across multiple scales}

Mechanisms of both decline and ecological restoration for protective forests have not been completely outlined. Research across multiple scales (e.g., tree, stand/wind break, and landscape) with the focus on the ecosystems need to be carried out (Zhu 2013). Early detection of protective forest decline as a useful management tool needs to be studied. In addition, techniques holding the promise for controlling the decline and improving the stability of protective forests, e.g., research matching species to site conditions, regulation of stand density, and resolving regeneration obstacles should be investigated (Zhu 2013; Parpan and Parpan 2017).

\section{Assessment of forestry eco-engineering procedure at large-scales based on ecosystem principles}

Assessment of the ecological effects of protective forests is important to forest management (Brang et al. 2006; Zagas et al. 2011) because it links theories and technologies, i.e., assessment is key to verifying scientific management practices and protective forests achieve their purpose. Additionally, assessment may explain the ecological mechanisms whereby protective forests function. In turn, the results can be applied to improve or guide management (Brang et al. 2006). Numerous assessment studies have been carried out on individual ecological mechanisms at meso- and smallscale levels which cannot meet management needs at largescales. Therefore, a comprehensive assessment of forestry eco-engineering procedures at the landscape and regional scales is necessary (Zhu and Zheng 2019). Although most research has been conducted on the functional mechanisms of protective forests, protective forests as an ecosystem is not well understood. Thus, research on ecological mechanisms of function and stability maintenance should be undertaken. In addition, climate changes will affect the survival, growth, and functions of protective forests through changes in temperature, rainfall, and increase in extreme weather events. Research on climatic effects on forestry eco-engineering programs and corresponding adaptive strategies to maintain the efficiency, stability, and sustainability of protective functions are topics for further research (Zhu and Zheng 2019).

\section{Conclusion}

Ecological mechanisms for management practices of protective forests are important orientations linking ecology with management, focusing on the application of biological, ecological, and social knowledge to manage and conserve 
protective forests. Considerable achievements have been made on ecological mechanisms for management, but there are information gaps that must be addressed. Management theories, structural optimization across multiple scales, decline mechanisms and corresponding ecological restoration, and assessment of protective forests should be studied at the landscape and regional scales on the basis of ecological principles. Climatic impacts of forestry eco-engineering programs and corresponding adaptive strategies to climate change also need to be addressed.

Acknowledgements We thank Dr. Mingcai Li and Deliang Lu for reviewing and polishing the manuscript. Ms. Jinxin Zhang provided assistance in formatting the manuscript and checking the references.

Open Access This article is licensed under a Creative Commons Attribution 4.0 International License, which permits use, sharing, adaptation, distribution and reproduction in any medium or format, as long as you give appropriate credit to the original author(s) and the source, provide a link to the Creative Commons licence, and indicate if changes were made. The images or other third party material in this article are included in the article's Creative Commons licence, unless indicated otherwise in a credit line to the material. If material is not included in the article's Creative Commons licence and your intended use is not permitted by statutory regulation or exceeds the permitted use, you will need to obtain permission directly from the copyright holder. To view a copy of this licence, visit http://creativecommons.org/licenses/by/4.0/.

\section{References}

Amichev BY, Bentham MJ, Cerkowniak D, Kort J, Kulshreshtha S, Laroque CP, Piwowar JM, Van Rees KCJ (2015) Mapping and quantification of planted tree and shrub shelterbelts in Saskatchewan, Canada. Agroforest Syst 89:49-65

Amichev BY, Laroque CP, Van Rees KCJ (2020) Shelterbelt removals in Saskatchewan, Canada: implications for long-term carbon sequestration. Agroforest Syst 94:1665-1680

Arundell JC, Straw NA (2001) Hornet clearwing moth (Sesia apiformis [Clerck]) and dieback of poplars in eastern England. Arboric J 25:235-253

Bayoumi AA (1977) The role of shelterbelts in Sudanese irrigated agriculture with particular reference to the Gezira. Part II. A proposed scheme for shelterbelts in the Gezira. Sudan Silva 3:35-38

Brain S (2010) The great Stalin plan for the transformation of nature. Environ Hist 15:670-700

Brandle JR, Hintz DL (1988) Windbreaks for the future. Agric Ecosyst Environ 22-23:593-596

Brandle JR, Laurie H, Zhou XH (2004) Windbreaks in North American Agricultural Systems. Agrofor Syst 61:65-78

Brang P, Schönenberger W, Frehner M, Schwitter R, Thormann JJ, Wasser B (2006) Management of protection forests in the European Alps: an overview. For Snow Landsc Res 80:23-44

Burke M, Rundquist B, Zheng H (2019) Detection of shelterbelt density change using historic APFO and NAIP aerial imagery. Remote Sens 11:218

Cao XS (1983) Shelterbelts for farmland. China Forestry Publishing House, Beijing, p. 645 (in Chinese)

Chavasse CGR (1982) Management of shelterbelts for wood products. New Zealand J For 27:189-206
Contreras-Hermosilla A (2000) The underlying causes of forest decline. Bogor, Indonesia, Centre of International Forest Research (CIFOR)

Cornelis WM, Gabriels D (2005) Optimal windbreak design for winderosion control. J Arid Environ 61:315-332

Deng RX, Li Y, Zhang SW, Shi XL (2011) Assessment of the effects of the shelterbelt on the soil temperature at regional scale based on MODIS data. J For Res 22:65-70

Dong ZB, Chen WN, Li ZS, Yang ZT (1996) The laboratory study on the role of vegetation in soil erosion by wind. J Soil Erosion Soil Water Conser 2:1-8 (in Chinese with English abstract)

Du XJ, Jiang FQ, Shen H, Lin HM (2002) Early diagnosis of lowvalue forest: An approach of ecological factors. Chin J Appl Ecol 13:1523-1528 (in Chinese with English abstract)

Fischer J, Stott J, Zerger A, Warren G, Sherren K, Forrester RI (2009) Reversing a tree regeneration crisis in an endangered ecoregion. Proc Natl Acad Sci USA 106:10386-10391

Franklin JF, Donato DC (2020) Variable retention harvesting in the Douglas-fir region. Ecol Process 9:8

Gardner R (2009) Trees as technology: Planting shelterbelts on the Great Plains. Hist Technol 25:325-341

Ge YX, Bi GY (2018) Ecological function evaluation of poplar shelterbelt in the plain regions. Prot Forest Sci Technol 5:41-42 (in Chinese with English abstract)

Ghimire K, Dulin MV, Atchison RL, Goodin DG, Hutchinson JMS (2014) Identification of windbreaks in Kansas using objectbased image analysis, GIS techniques and field survey. Agrofor Syst 88:1-11

Grant PF, Nickling WG (1998) Direct field measurement of wind drag on vegetation for application to windbreak design and modelling. Land Degrad Dev 9:57-66

Heisler GM, Dewalle DR (1988) Effects of windbreak structure on wind flow. Agric Ecosyst Environ 22(23):41-69

Huang FX, Niu HS, Wang MX, Wang YS, Ding GD (2001) The relationship between vegetation cover and sand transport flux at Mu Us Sandland. Acta Geogr Sin 56:700-710 (in Chinese with English abstract)

Iwasaki K, Torita H, Abe T, Uraike T, Touze M, Fukuchi M, Sato H, Iijima T, Imaoka K, Igawa H (2019) Spatial pattern of windbreak effects on maize growth evaluated by an unmanned aerial vehicle in Hokkaido, northern Japan. Agroforest Syst 93:1133-1145

Ji YH, Zhou GS, Li ZS, Wang SD, Zhou HL, Song XY (2020) Triggers of widespread dieback and mortality of poplar (Populus spp.) plantations across northern China. J Arid Environ 174:104076

Jiang FQ, Zhu JJ, Zeng DH, Fan ZP, Du XJ, Cao YC (2003) Management for protective plantations. China Forestry Publishing House, Beijing. p 353 (in Chinese with English brief introduction)

Jiao SR (2001) Report on the causes of the early decline of Pinus sylvestris var. mongolica shelterbelt and its preventative and control measures in Zhanggutai of Liaoning province. Sci Silv Sin 37:131-138 (in Chinese with English abstract)

Josephson P (2019) Introduction: The Stalin Plan for the transformation of nature, and the east European experience. In: Olšáková D (ed) In the name of the great work: Stalin's Plan for the transformation of nature and its impact in eastern Europe. Berghahn Books, New York, Oxford, pp 1-42

Jose S (2012) Agroforestry for conserving and enhancing biodiversity. Agroforest Syst 85:1-8

Kenney WA (1987) A method for estimating windbreak porosity using digitized photographic silhouettes. Agric Forest Meteorol 39:91-94

Lexer MJ, Bugmann H (2017) Mountain forest management in a changing world. Eur J Forest Res 136:981-982

Li X, Xiao QF, Niu JZ, Dymond S, McPherson EG, van Doorn N, Yu XX, Xie BY, Zhang KB, Li J (2017) Rainfall interception by 
tree crown and leaf litter: An interactive process. Hydrol Process 31:3533-3542

Limousin JM, Rambal S, Ourcival JM, Joffre R (2008) Modelling rainfall interception in a mediterranean Quercus ilex ecosystem: Lesson from a throughfall exclusion experiment. J Hydrol 357:57-66

Loeffler AE, Gordon AM, Gillespie TJ (1992) Optical porosity and windspeed reduction by coniferous windbreaks in Southern Ontario. Agroforest Syst 17:119-133

Masaka K, Wakita Y, Iwasaki K, Hayamizu M (2020) Degradation of white birch shelterbelts by attack of white-spotted longicorn beetle in central Hokkaido, northern Japan. BioRxiv. https://doi. org/10.1101/2020.01.30.926188

Mayrinck RC, Laroque CP, Amichev BY, Rees KV (2019) Aboveand below-ground carbon sequestration in shelterbelt trees in Canada: a review. Forests 10:922

Miralles DG, Gash JH, Holmes TRH, de Jeu RAM, Dolman AJ (2010) Global canopy interception from satellite observations. J Geophys Res 115:D16122

Mize CW, Brandle JR, Schoeneberger MM, Bentrup G (2008) Ecological development and function of shelterbelts in temperate North America. In: Jose S, Gordon AM (eds) Toward Agroforestry Design: An Ecological Approach. Springer, Netherlands, Dordrecht, pp 27-54

Motta R, Haudemand JC (2000) Protective forests and silvicultural stability. Mt Res Dev 20:180-187

Morales-Hidalgo D, Oswalt SN, Somanathan E (2015) Status and trends in global primary forest, protected areas, and areas designated for conservation of biodiversity from the global forest resources assessment 2015. For Ecol Manage 352:68-77

Nair PR, Nair VD, Kumar BM, Showalter JM (2010) Carbon sequestration in agroforestry systems. Adv Agron 108:237-307

Nerlich K, Graeff-Hönninger S, Claupein W (2013) Agroforestry in Europe: A review of the disappearance of traditional systems and development of modern agroforestry practices, with emphasis on experiences in Germany. Agroforest Syst 87:475-492

Orth J (2007) The shelterbelt project: Cooperative conservation in 1930s America. Agr Hist 81:333-357

Osorio RJ, Barden CJ, Ciampitti IA (2019) GIS approach to estimate windbreak crop yield effects in Kansas-Nebraska. Agroforest Syst 93:1567-1576

Park A, Cameron JL (2008) The influence of canopy traits on throughfall and stemflow in five tropical trees growing in a Panamanian plantation. For Ecol Manage 255:1915-1925

Parpan TV, Parpan VI (2017) Aboveground biomass of common oak windbreaks in the central part of Ukraine. Sci Bull UNFU 27:59-63

Pisarenko AI, Strakhov VV, Päivinen R, Kuusela K, Dyakun FA, Sdobnova VV (2001) Development of forest resources in the European part of the Russian Federation (European Forest Institute Research Rep. N 11). Koninklijke Brill NV, Leiden

Ren ZP, Li ZB, Liu XL, Cheng SD, Xu GC (2018) Comparing watershed afforestation and natural revegetation impacts on soil moisture in the semiarid Loess Plateau of China. Sci Rep 8:2972

Schößer B, Helming K, Wiggering H (2010) Assessing land use change impacts-a comparison of the SENSOR land use function approach with other frameworks. J Land Use Sci 5:159-178

Shaw D (2015) Mastering nature through science: Soviet geographers and the Great Stalin plan for the transformation of nature, 1948-53. Slavonic East Eur Rev 93(1):120-146

Song LN, Zhu JJ, Yan QL (2009) Review on the shelter forest decline. Chin J Ecol 28:1684-1690 ((in Chinese with English abstract)

Song LN, Zhu JJ, Zhang JX, Yang K, Lü LY, Zhang JX, Hao GY (2020) Transpiration and canopy conductance dynamics of Pinus sylvestris var. mongolica in its natural range and in an introduced region in the sandy plains of Northern China. Agric Forest Meteorol 281:107830

Stange C (1996) Windbreak management. School of papers in natural resources, University of Nebraska, Lincoln

Sun SJ, He CX, Qiu LF, Li CY, Zhang JS, Meng P (2018) Stable isotope analysis reveals prolonged drought stress in poplar plantation mortality of the Three-North Shelter Forest in Northern China. Agric Forest Meteorol 252:39-48

Thuyet DV, Do TV, Sato T, Hung TT (2014) Effects of species and shelterbelt structure on wind speed reduction in shelter. Agroforest Syst 88:237-244

Thom D, Seidl R (2016) Natural disturbance impacts on ecosystem services and biodiversity in temperate and boreal forests. Biol Rev 91:760-781

Vacek S, Khel T, Sharma RP, Kučera J, Král J, Papaj V (2018) Windbreak efficiency in agricultural landscape of the Central Europe: Multiple approaches to wind erosion control. Environ Manage 62:942-954

Vales DJ, Bunnell FL (1988) Comparison of methods for estimating forest overstory cover. 1. Observer effects. Can J For Res 18:606-609

Wang HC, Cui WS, Kou WZ (2000) On the conception of protective maturation of protection forests. J Beijing For Univ 22:81-85 (in Chinese with English abstract)

Wang T (2004) Progress in sandy desertification research of China. J Geogr Sci 14:387-400

Wu TG, Zhang P, Zhang L, Wang JY, Yu MK, Zhou XH, Wang GG (2018) Relationships between shelter effects and optical porosity: A meta-analysis for tree windbreaks. Agric Forest Meteorol 259:75-81

Yang XG, Yu Y, Fan YW (2017) A method to estimate the structural parameters of windbreaks using remote sensing. Agroforest Syst 91:37-49

Zagas TD, Raptis DI, Zagas DT (2011) Identifying and mapping the protective forests of southeast Mt. Olympus as a tool for sustainable ecological and silvicultural planning, in a multi-purpose forest management framework. Ecol Eng 37:286-293

Zhao YZ, Mu XM, Yan BW, Zhao GJ (2015) Meta-analysis on runoff and sediment reductions of re-vegetation with different planting years on Loess Plateau. Bull Soil Water Conserv 35:6-11 (in Chinese with English abstract)

Zheng X, Zhu JJ, Yan QL, Song LN (2012) Effects of land use changes on groundwater table and the decline of Pinus sylvestris var. mongolica plantations in the Horqin Sandy Land, Northeast China. Agr Water Manage 109:94-106

Zheng X, Zhu JJ, Xing Z (2016) Assessment of the effects of shelterbelts on crop yields at the regional scale in Northeast China. Agr Syst 143:49-60

Zhou XH, Sun ZW (1994) On measuring and evaluating the spatial pattern of shelterbelt networks in landscape. Acta Ecol Sin 14:24-31 (in Chinese with English abstract)

Zhou XH, Brandle JR, Takle ES, Mize CW (2002) Estimation of the three-dimensional aerodynamic structure of a green ash shelterbelt. Agric Forest Meteorol 111:93-108

Zhou XH, Brandle JR, Mize CW, Takle ES (2005) Three-dimensional aerodynamic structure of a tree shelterbelt: definition, characterization and working models. Agroforest Syst 63:133-147

Zhu JJ, Matsuzaki T, Gonda Y (2003) Optical stratification porosity as a measure of vertical canopy structure in a Japanese pine coastal forest. For Ecol Manage 173:89-104

Zhu JJ (2008) Wind shelterbelts. In: Jørgensen SE, Fath BD (eds) Encyclopedia of Ecology. Academic Press, Oxford, pp 3803-3812

Zhu JJ, Li FQ, Xu ML, Kang HZ, Wu XY (2008) The role of ectomycorrhizal fungi in alleviating pine decline in semiarid sandy 
soil of northern China: an experimental approach. Ann For Sci 65(3):304p1-304p12

Zhu JJ (2013) A review of the present situation and future prospect of science of protective forests. Chin J Plant Ecol 37:872-888 (in Chinese with English abstract)

Zhu JJ, Zheng X (2019) The prospects of development of the ThreeNorth Afforestation Program (TNAP): On the basis of the results of the 40-year construction general assessment of the TNAP. Chin J Ecol 38:1600-1610 (in Chinese with English abstract)

Publisher's Note Springer Nature remains neutral with regard to jurisdictional claims in published maps and institutional affiliations. 